\title{
NOTA ADICIONAL SOBRE BORGES Y EL QUIJOTE
}

"La conducta novelística de Cervantes', un ensayo de El idioma de los argentinos (1928), uno de los libros primerizos luego rechazados de Borges, contiene en germen la visión del Quijote expuesta en "Análisis del último capítulo del Quijote" ". El destino de Don Quijote es más "dejado de la mano de su dios”' que ningún otro "destino escrito"'3. Esto es así porque la "conducta novelística" de Cervantes es "paradójica y arriesgada" (ibid.). Cervantes elabora una hagiografía de su personaje, pero de un modo "desaforado" (p. 140), provocando en nosotros "una reacción compasiva o hasta enojada frente a las indignidades sin fin que injurian al héroe" (ibid.). Tejiendo y destejiendo "la admirabilidad" de Don Quijote, Cervantes "lo levanta a semidiós" (p. 141).

Compara Borges de paso los dos Quijotes: el primero, con sus “cargosas retahílas de palos y puñetazos", le parece muy secundario "en mérito" al segundo, donde "El arte de Cervantes, diez años mayor, asume [...] toda la audacia peligrosísima de su destreza y pone a Don Quijote, no ya en el inventado riesgo de que le peguen, sino en el verdadero y muy serio de que le perdamos cariño" (ibid.), con lo cual "las tentaciones en que puede caer el lector son más considerables y más sutiles" (ibid.). Ejemplos de esos "riesgos" son la soledad del héroe, "la única soledad que ocurre en la literatura del mundo", pues a diferencia de lo que les sucede a Prometeo, Hamlet o Raskolnikov, nadie se comunica con él. "Don Quijote está solo, y cualquier eventualidad lo interrumpe', (p. 142), según prueban las historias llamadas inter-

1 Esta nota es continuación de “El Quijote según Borges", $N R F H, 36$ (1988), 477-500.

${ }^{2}$ RUBA, 1956, núm. 1, 28-36.

${ }^{3}$ El idioma de los argentinos, M. Gleizer, Buenos Aires, 1928, p. 139. 
poladas. Ni aun su muerte consigue "ocupar la franca y solemne atención de su historiador", quien lo hace arrepentirse "de su heroísmo, apostasía inútil, para mencionar después casualmente y en la mitad de un párrafo, que falleció" (ibid.). Ni siquiera se le concede ser inconsciente de su rareza, que afirma en la aventura de los santos de palo.

Finalmente, se detiene Borges en los consejos de Don Quijote a Sancho a propósito de su gobierno de la "ínsula". No importa que esos consejos no sean insólitos (aquí aprovecha Borges para burlarse de Américo Castro - según haría de nuevo en "Las alarmas del doctor Américo Castro", incluido en Otras inquisiciones-, que así lo nota "en su libro encaminado a probar que Cervantes vivió de veras en el siglo xvi y en su atmósfera" [p. 144]); lo que llama la atención es el darlos sin que Sancho los pida y de modo "coercitivo", como "una continuación de la autoridad del hidalgo", sugiriendo que éste envidia la suerte de su escudero (p. 145). “ ¿No es más odiosa la sola insinuación de esa envidia que esa otra obscena aventura en que tirado Don Quijote en el campo, cruza una piara de cerdos encima de él?', se pregunta Borges, concluyendo que "esos atropellos y desmanes" "evidencian la confianza de su escritor en la invulnerabilidad esencial de su héroe. Sólo en Cervantes ocurren valentías de ese orden"' (p. 146).

En el segundo párrafo del ensayo, y antes de describir ćomo trata Cervantes a su héroe, plantea Borges dos tesis que aparecen elaboradas en la nota de Realidad, "Magias parciales del Quijote", "Parábola de Cervantes y de Quijote", y, además, en "Análisis del último capítulo del Quijote" 4 . Resulta errado creer, como pretende el propio Cervantes, que el Quijote sea una pura parodia de los libros de caballería (p. 139), y es igualmente erróneo ver la novela como "una repartición de nuestra alma en dos apuradas secciones: la de la siempre desengañada generosidad y la de lo práctico" (ibid.). La primera lectura convierte al Quijote en una obra circunstancial; la segunda en alegoría. Pero el Quijote es "la venerable y satisfactoria presentación de una gran persona, pormenorizada a través de doscientos trances, para que lo conozcamos mejor' (p. 140).

En otra sección del mismo libro, Borges, para mostrar cómo entendemos psicológicamente una oración, usa de ejemplo la primera del Quijote (pp. 10 ss). Tratando de la literatura española en

4 "Nota sobre el Quijote", Realidad. Revista de ideas, 2 (1947), 234-236; Otras inquisiciones (1952); El hacedor (1960); "Análisis. .", art. cit. 
general, que llama "fastidiosa", exceptúa de esa caracterización al Quijote: "'algún ejemplo de genialidad española vale por literaturas enteras: don Francisco de Quevedo, Miguel de Cervantes. ¿Quién más?'” (p. 174).

Reseñando, en 1936, la novela El perseguidor, de Louis Golding, nota Borges que si tenemos en cuenta a Macbeth, Hamlet, el Rey Lear, Raskolnikov, Lord Jim y Don Quijote, “el protagonista de un drama o de una novela tiene que ser un loco", cuya locura ("posibilidad terrible de cualquier alma"), el autor debe mostrar cómo se origina y crece; lo cual, sin embargo, Cervantes no hace, sino que asume esa locura desde el comienzo del Quijote ${ }^{5}$.

El prólogo a La invención de Morel, de Bioy Casares (1940), menciona al Quijote negativamente, junto al Asno de oro y "Los viajes de Simbad". Estas obras se caracterizan por "la mera variedad sucesiva", en la que trata - rigurosamente- de no incurrir la novela de aventuras ${ }^{6}$.

En una "Nota de un mal lector", sobre Ortega y Gasset?, menciona Borges despectivamente el "fatigoso refranero de Sancho" (empleado a menudo para demostrar "la primacía del castellano", que queda así reducida a "idiotismos'). Pero añade, en elogio de Cervantes: “Así, de paradójico modo, los literatos españoles buscaron la grandeza del español en las aldeanerías y fruslerías rechazadas por Cervantes y por Quevedo...'.

La "nota" trata principalmente de una comparación entre Ortega y Unamuno, al que Borges prefiere, mas admitiendo que quizá esté errado en ello, lo mismo que "Alguna vez juzgué inexplicable que las generaciones de los hombres veneraran a Cervantes y no a Quevedo", lo que hoy no le parece ya "misterioso".

La base para esa admiración por Cervantes aparece explicada en 'La supersticiosa ética del lector', de Discusión (1932), ensayo dedicado a atacar el culto al estilo entendido como técnica, como el criterio para juzgar una obra literaria, en lugar de "la propia convicción o propia emoción'”8. Borges pone como ejem-

${ }^{5}$ Jorge Luis Borges, Textos cautivos. Ensayos y reseñas en "El Hogar.", eds. Enrique Sacerio-Garí y Emir Rodríguez Monegal, Tusquets Editores, Barcelona, 1986, p. 58.

${ }^{6}$ Adolfo Bioy Casares, La invención de Morel, Emecé, Buenos Aires, 1970 , p. 12.

7 Ciclón, La Habana, 2 (1956), p. 28. (Cit. por Roberto González Eche. VARría, Isla a su vuelo fugitiva, José Porrúa Turanzas, Madrid, 1983, pp. 224225.)

${ }^{8}$ Discusión, Alianza Editorial, Madrid, 1964, p. 39. 
plo el Quijote: “'La crítica española, ante la probada excelencia de esa novela, no ha querido pensar que su mayor (y tal vez único irrecusable) valor fuera el psicológico, y le atribuyen dones de estilo, que a muchos parecerán misteriosos. En verdad, basta revisar unos párrafos del Quijote para sentir que Cervantes no era estilista (a lo menos en la presente acepción acústico-decorativa de la palabra)", pues estaba demasiado interesado en "los destinos de Quijote y de Sancho para dejarse distraer por su propia voz"' (p. 40).

La noción de que el estilo de Cervantes es defectuoso, la cual ya encontramos en el prólogo de Borges a una edición de las $\mathrm{No}^{-}$ velas ejemplares $^{9}$, la sostiene éste con menciones de Gracián, quien "'no se resuelve a acordarse de Don Quijote"'; de Quevedo, quien "versifica en broma su muerte y se olvida de él", y con citas de dos admirados autores argentinos (franco-argentino el segundo) de quienes extrajo, sin duda, esa convicción tan contraria a la compartida por la crítica cervantina, factor éste que indudablemente influye en el que Borges la sostenga, quizá incluso con cierto fervor nacionalista. Lugones acusa el estilo de Cervantes de "Pobreza de color, inseguridad de estructura, párrafos jadeantes que nunca aciertan con el final [ . . ] repeticiones, falta de proporción" (ibid.); Groussac de "flojo y desaliñado", repetitivo, grandilocuente; de ser, en fin, "prosa de sobremesa" (p. 41). Esa definición le parece a Borges la más acertada para la cervantina: "Prosa de sobremesa, prosa conversada y no declamada, es la de Cervantes, y otra no le hace falta. Imagino que esa misma observación será justiciera en el caso de Dostoievski o de Montaigne o de Samuel Butler' (ibid.).

$\mathrm{Y}$, sin embargo, precisamente porque no aspira a la perfección que hace que ninguna de sus palabras pueda "ser alterada sin daño" (ibid.), el Quijote "gana póstumas batallas contra sus traductores y sobrevive a toda descuidada versión [ . . . Más vivo es el fantasma alemán o escandinavo o indostánico del Quijote que los ansiosos artificios verbales del estilista'” (p. 42).

JUlio RoDríguez-Luis State University of New York

${ }^{9}$ Novelas ejemplares, Emecé, Buenos Aires, 1946, pp. 9-11. 